\title{
PENGEMBANGAN SISTEM INFORMASI KOPERASI DENGAN MENGGUNAKAN METODE WEB BASED ENGINEERING
}

\author{
SURTIKANTI \\ Staf Pengajar Fakultas Teknik Prodi Teknik Informatika \\ Universitas Pamulang, Tangerang Selatan, Banten \\ email:khantie@gmail.com
}

\begin{abstract}
ABSTRAK
Kegiatan utama Koperasi adalah melakukan transaksi simpan pinjam, dalam hal ini hanya diperuntukkan khusus anggota koperasi saja. Setiap transaksi yang dilakukan masih menggunakan cara manual dan berkas form data akan disimpan ke dalam berkas penyimpanan data yang ada. Pengarsipan menggunakan media kertas memerlukan banyak tempat, pemeliharaan dan pencariannya menjadi sulit karena harus melakukan pencarian dari sekumpulan kertas. Begitu juga dengan pengarsipan elektronik, perlu dilakukan pengelolaan yang baik.

Sistem dikembangkan dengan menggunakan metode Webbased Engineering dengan pendekatan Waterfall yang terbagi atas empat tahap yaitu definisi kebutuhan, perancangan sistem, implementasi serta integrasi dan pengujian sistem. Sedangkan bahasa pemrograman yang digunakan adalah $P H P$ dan dipadukan dengan database MySql. Sistem yang dikembangkan perlu diuji dengan pengujian Blackbox dan Whitebox sehingga hasil pengembangan dapat sesuai dengan yang diharapkan. Sistem informasi koperasi yang dihasilkan diharapkan dapat digunakan oleh Koperasi Wanita Pondok Petir dalam mengatasi permasalahan yang dihadapi selama ini.
\end{abstract}

Kata kunci: Sistem, Informasi, Koperasi, Web Based Engineering

\section{PENDAHULUAN}

\subsection{Latar Belakang}

Teknologi informasi turut berkembang sejalan dengan peradaban zaman. Perkembangan teknologi informasi tidak hanya mempengaruhi dunia bisnis tetapi termasuk juga kegiatan koperasi. Koperasi merupakan organisasi ekonomi yang berusaha menggerakkan sumber daya ekonomi demi memajukan kesejahteraan anggota. Pada sebuah lembaga atau instansi ketepatan akan sebuah informasi sangatlah penting, demikian juga pada sebuah Koperasi. Pengolahan data yang baik dan benar dapat menghasilkan sebuah informasi yang akurat dan dapat mempermudah petugas dalam proses pencarian data.

Oleh karena itu penulis ingin mengembangkan sebuah sistem informasi koperasi yang berbasis web. Sistem ini diharapkan dapat bermanfaat untuk pengembangan koperasi simpan pinjam dalam mengelola data yang ada di koperasi.

\section{METODE PENELITIAN}

\subsection{Metode Web Based Engineering}

Rekayasa web adalah proses yang digunakan untuk menciptakan aplikasi web yang berkualitas tinggi (Pressman \& Lowe, Web Engineering APractitioner's Approach, 2009:18). Rekayasa web mengadaptasi rekayasa perangkat lunak dalam hal konsep dasar yang menekankan pada aktifitas teknis dan manajemen. Namun demikian adaptasi tidak secara utuh, tapi dengan perubahan dan penyesuaian. Rekayasa web gabungan antara webpublishing (suatu konsep yang berasal dari printed publishing) dan aktifitas rekayasa perangkat lunak. Dikatakan demikian karena desain sebuah aplikasi web menekankan pada desain grafis, desain informasi, teori hypertext, desain sistem dan pemrograman.

\subsection{Web Engineering}

Web engineering didefinisikan sebagai pendirian prinsip ilmiah, teknik, dan manajemen serta disiplin yang diaplikasikan dengan pendekatan sistematis menuju pengembangan, penyebaran, dan pemeliharaan sistem dan aplikasi berbasis web yang berkualitas tinggi 
(Pressman R. S., 2010:769). Web engineering memfokuskan diri terhadap aplikasi metodologi, teknik, dan kakas dalam desain dan pengembangan perangkat lunak berbasis web.

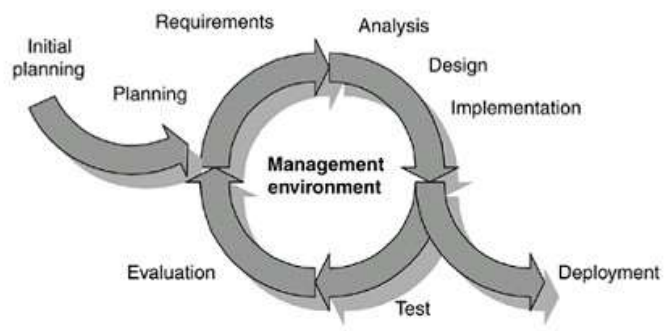

Gambar 2.4 Aktivitas Web Engineering (Pressman \& Lowe, 2009:176)

\section{PEMBAHASAN}

\subsection{Struktur Navigasi Website}

Struktur Navigasi disebut juga dengan hubungan satu halaman kehalaman berikutnya dalam suatu direktori halaman homepage, dengan menggunakan fasilitas hyperlink. Website ini menggunakan struktur navigasi Hirarki. Dimulai dengan halaman Login, Beranda khusus Admin (Bendahara), Menu utama yang terdiri dari Daftar Pinjaman, Transaksi Angsuran, Transaksi Simpanan,

\section{Construction}

Construction merupakan proses membuat kode. Coding atau pengkodean merupakan penerjemah desain dalam bahasa yang bisa dikenali oleh komputer. Programmer akan menerjemahkan transaksi yang diminta oleh user.

Tahapan inilah yang merupakan tahapan secara nyata dalam mengerjakan suatu software, artinya penggunaan komputer akan dimaksimalkan dalam tahapan ini.

Setelah pengkodean selesai maka akan dilakukan testing terhadap sistem yang telah dibuat tadi.

Tujuan testing adalah menemukan kesalahan-kesalahan terhadap sistem tersebut untuk kemudian bisa diperbaiki.

a. User Login 1

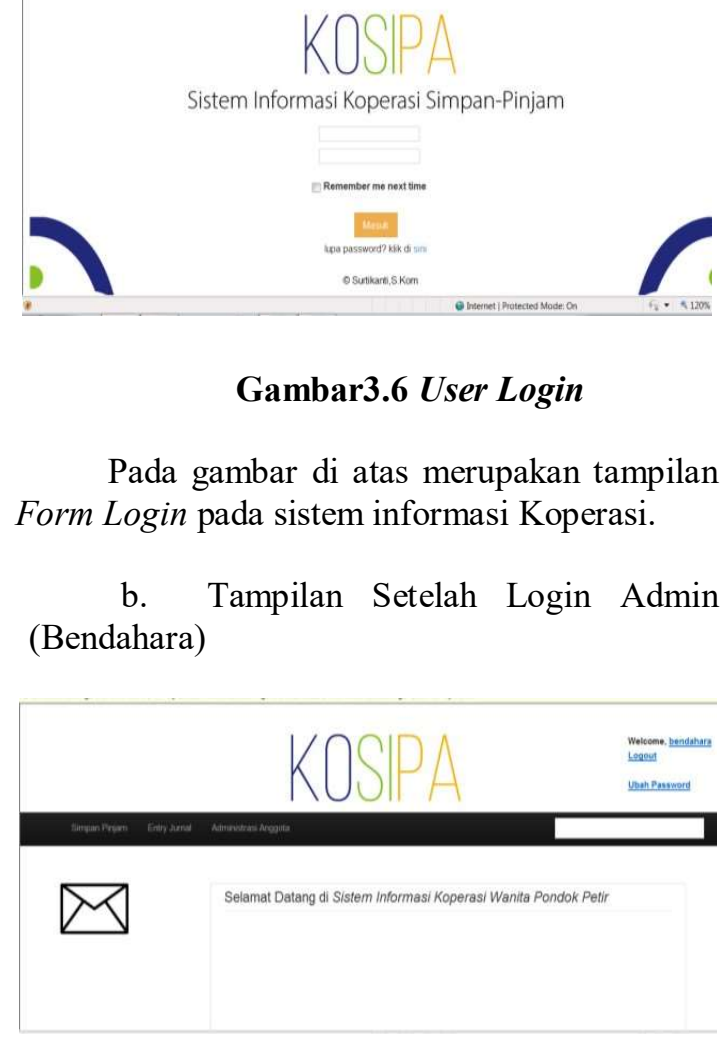

Gambar 3.7 Tampilan Setelah Login Admin (Bendahara)

Pada gambar di atas merupakan tampilan setelah Login untuk Admin (Bendahara) dan langsung masuk ke Menu Utama pada sistem informasi Koperasi yang akan di buat.

c. Tampilan Transaksi Peminjaman

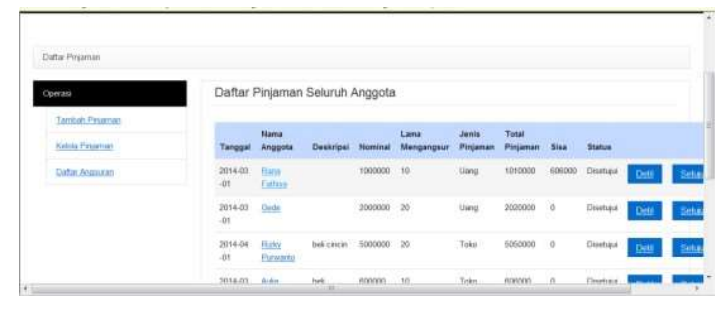

Gambar 3.8Tampilan Form Transaksi Peminjaman

Pada gambar di atas merupakan tampilan Form Transaksi Pinjaman Koperasi di Menu Utama pada sistem informasi Koperasi yang akan di buat.

d. Tampilan Transaksi Angsuran 


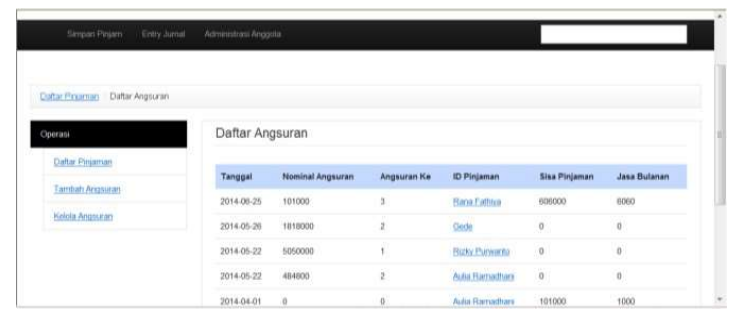

Gambar 4.9 Tampilan Form Transaksi Angsuran

Pada gambar di atas merupakan tampilan Form Transaksi Angsuran Anggota Koperasi di Menu Utama pada sistem informasi Koperasi yang akan di buat.

e. Tampilan Transaksi Simpanan Anggota

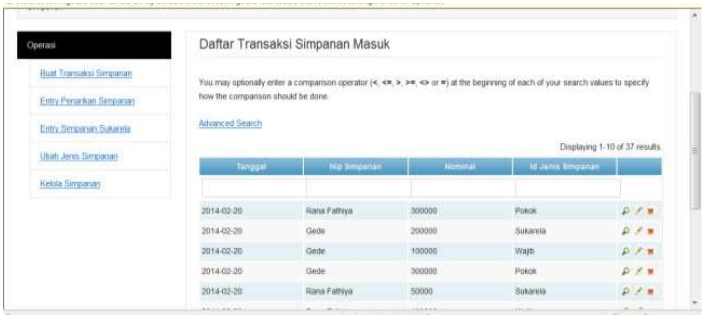

Gambar 4.10 Tampilan Form Transaksi Simpanan Anggota

Pada gambar di atas merupakan tampilan Form Transaksi Simpanan Anggota Koperasi di Menu Utama pada sistem informasi Koperasi.

\section{KESIMPULAN}

Untuk mengembangkan sistem informasi Koperasi yang menggunakan metode Web Based Engineering dengan pendekatan Waterfall maka dengan berdasarkan hasil penelitian dan pembahasan sebelumnya, dapat diambil kesimpulan berikut:

Penerapan metode Web Based Engineering dalam melakukan analisis dan merancang sistem informasi dipadukan dengan pendekatan waterfall. Dalam analisis, pendekatan waterfall diawali dengan analisa kebutuhan sistem dengan mengidentifikasi masalah-masalah yang dihadapi Koperasi. Berdasarkan permasalahan yang telah dirumuskan, maka dilakukan mengidentifikasi kebutuhan pengguna dan memodelkan sistem manual yang sedang berjalan pada Koperasi saat ini dengan menggunakan diagram UML, antara lain diagram use case dan diagram aktivitas yang menggambarkan proses kerja dan aktivitas dari keseluruhan sistem berjalan, serta dirincikan dengan menggunakan diagram komunikasi dari setiap aktivitas. Selain itu, juga dilakukan penggambaran tampilan antarmuka masukan dan keluaran dari sistem manual yangsedang berjalan sehingga diperoleh gambaran secara menyeluruh mengenai sistem manual yang sedang berjalan. Gambaran sistem manual sedang berjalan ini digunakan untuk analisis kebutuhan sistem yang juga dimodelkan dengan menggunakan diagram UML, yaitu diagram use case untuk memberikan gambaran secara umum sistem yang akan dikembangkan. Berdasarkan hasil analisis sebelumnya, maka dilanjutkan pada tahapan kedua yaitu perancangan sistem dengan penggambaran diagram kelas untuk menggambarkan kelas-kelas yang terlibat dalam sistem yang dikembangkan, merancang skema basis data dengan database MySql dan antarmuka sistem.

Pengimplementasian dan pengujian sistem merupakan tahapan selanjutnya dari tahap analisis dan merancang sistem pada metode $\mathrm{Web}$ Based Engineering dengan pendekatan waterfall Berdasarkan hasil rancangan antarmuka sistem dan skema basis data, maka dapat dilakukan pengimplementasi sistem, yaitu mengkodekan rancangan sistem yang akan dikembangkan dengan menggunakan bahasa pemrograman PHP Hasil implementasi tersebut dilakukan pengujian secara terintegrasi dengan menggunakan pengujian Blackbox untuk menguji kesesuaian informasi yang dikeluarkan terhadap data yang dimasukkan dan pengujian Whitebox untuk menguji alur logika dari hasil pengimplementasian sebelumnya. Hasil pengujian dengan pengujian Blackbox dan Whitebox menunjukkan kesesuaian dengan harapan sistem yang dikembangkan dapat memenuhi kebutuhan koperasi.

Untuk dapat melakukan penemuan kembali data yang telah diarsip, sistem menyediakan fasilitas untuk pencarian data yang disertai dengan Kode maupun berkas pendukung lainnya. Pencarian data dapat dilakukan dengan menggunakan Kode data yang dicari.

\section{SARAN}

Penulis menyadari bahwa masih banyak kekurangan dalam aplikasi ini, aplikasi ini masih dapat di kembangkan lebih luas lagi agar dapat memenuhi kebutuhan koperasi di masa yang akan datang. Adapun saran-saran yang disampaikan sebagai bahan pertimbangan untuk 
melengkapi penelitian ini dimasa yang akan datang adalah sebagai berikut:

Perlu ditambahkan fitur laporan grafik untuk mengukur kinerja koperasi dalam melakukan transaksi per periode / tahun.

\section{DAFTAR PUSTAKA}

Koperasi, K. (2008). Standard Operating procedure KSP/ USP. In Koperasi (p. 7). Depok.

Pressman. (2010:29).

Pressman. (2010:39). A PRACTITIONER'S APPROACH.

Pressman, \& Lowe. (2009:18). Web Engineering APractitioner's Approach.

Pressman, R. S. (2010:769). A PRACTITIONER'S APPROACH. In F. EDITION. Boston Burr Ridge, IL Dubuque, IA Madison, WI New York San Francisco St. Louis: www.BZUpages.COM.

Pressman, R. S., \& Lowe, D. (2009:176).

1221 Avenue of the Americas, New York, NY 10020.: McGraw-Hill, a business unit of The McGraw-Hill Companies, Inc.

Soesilo, H. I. (2012 : 36). Dinamika Gerakan Koperasi Indonesia. Indonesia: Serambi.

Winston, R. W. (1970:330). Managing The Development Of Large Software Sysem. The Institute of Electronics Engineers. 